\title{
Kajian Semiotika pada Video Musik di Udara - Efek Rumah Kaca dalam Konteks Politik
}

\author{
Yunisa Fitri Andriani'), Vicky Septian Rahman ${ }^{2)}$ \\ Desain Komunikasi Visual, Institut Teknologi dan Bisnis Kalbis \\ J1. Pulomas Selatan Kav. 22, Jakarta Timur 13210 \\ ${ }^{1)}$ Email: yunisa.andriani@kalbis.ac.id \\ ${ }^{2)}$ Email:vicky.rahman@kalbis.ac.id
}

\begin{abstract}
Injustice certainly occurs between communities, especially in politics. This injustice gave birth to activists who fought to defend the rights of the people who were victims of oppression, violence, kidnapping and so on. One of the human rights activists in Indonesia, Munir, who died because he was poisoned on his way to Amsterdam, Netherlands, became the inspiration for a music group called Efek Rumah Kaca on their song 'Di Udara'. This pop genre song full of political messages conveyed to the community aims to inflame the spirit of activists and is expected to give birth to a new Munir. The political message packaged in the music video for the song 'Di Udara' is the focus of this research study. Through the study method all signs and codes contained in the visuals contained in this music video were analyzed using the sign theory namely Semiotics. The purpose of this study was to inflame the spirit of activists and facilitate the delivery of activists'messages through music videos.
\end{abstract}

Keywords: music videos, semiotics, political, messages

\begin{abstract}
Abstrak: Ketidakadilan tentu terjadi diantara masyarakat terutama dalam dunia politik. Ketidakadilan ini yang kemudian melahirkan para aktivis yang berjuang membela hak masyarakat yang menjadi korban penindasan, kekerasan, penculikan dan lain sebagainya. Salah satu aktivis hak asasi manusia di Indonesia, Munir yang meninggal karena diracun dalam perjalanannya menuju Amsterdam, Belanda menjadi inspirasi sebuah kelompok music Efek Rumah Kaca dalam lagu mereka yang berjudul 'D $i$ Udara'. Lagu bergenre pop ini sarat akan pesan politik yang disampaikan pada masyarakat bertujuan untuk mengobarkan semangat para aktivis dan diharapkan dapat melahirkan Munir-munir baru. Pesan politik yang dikemas dalam video music lagu 'Di Udara' ini menjadi fokus kajian penelitian ini. Melalui metode kajian seluruh tanda dan kode yang terkandung dalam visual yang terdapat di dalam video musik ini dianalisa dengan menggunakan teori tanda yaitu Semiotika.Tujuan dari penelitian ini adalah untuk mengobarkan semangat para aktivis dan mempermudah penyampaian pesan para aktivis melalui video musik.
\end{abstract}

Kata kunci: semiotika, video musik, politik, pesan

\section{PENDAHULUAN}

Munir merupakan aktivis Hak Asasi Manusia Indonesia. Selama ini ia dikenal gigih dalam memperjuangkan orang-orang yang tertindas dan mendapat perlakuan kasar. Munir pernah menjabat sebagai dewan kontras dan ketika itu namanya melambung sebagai pejuang bagi orang-orang hilang yang diculik. Munir membela para aktivis yang menjadi korban penculikan Tim Mawar dari Kopassus. Namun perjuangan Munir terhenti di tengah perjalanannya menuju Amsterdam, Belanda. Selain Munir Beberapa aktivis di Indonesia berjuang demi masyarakat namun diperlakukan tidak adil oleh pemerintah. Indonesia masih membutuhkan semangat seorang Munir, namun isu mengenai Munir dan aktivis lain hanya beredar di kalangan aktivis saja. Masyarakat perlu tahu apa yang dilakukan Munir dan apa yang dilakukan Negara terhadapnya agar semangat seorang Munir tidak hilang terkubur bersama jasadnya.

Efek Rumah Kaca ialah sebuah band indie yang saat ini pamornya kian melambung karena lagu-lagunya yang sarat akan kritik sosial. Mereka terinspirasi oleh kisah Munir dan kemudian mengangkat tema tersebut ke dalam salah satu lagu mereka. Efek Rumah Kaca mengemas kisah tersebut dengan budaya pop. Menurut band ini, aliran musik pop lebih mudah diterima oleh masyarakat, karena memang saat ini musik pop tengah merajai telinga penduduk Indonesia. Di tangan cholil vokalisnya, kisah seorang aktivis dituang dalam lagu berjudul 'Di 
Udara'. Judul tersebut dipilih berdasarkan kronologi kematian Munir yang terjadi di pesawat yang sedang melaju di angkasa. Lirik lagu ini berisi cerita tentang aktivis-aktivis di Indonesia, memuat perjuangan serta ketidak adilan yang diterima oleh para aktivis. Namun disamping itu, cerita Munir tetap menjadi fokus utama lagu ini.

Baik masyarakat maupun band Efek Rumah Kaca itu sendiri tidak tahu apakah lagu ini berhasil menumbuhkan semangat Munir-Munir lain atau tidak. Selain lagu, band indie ini membuat music video untuk lagu tersebut. Mereka berharap jika dibantu dengan visual, pesan perjuangan para aktivis dapat lebih melekat di hati masyarakat. Emosi serta semangat masyarakat pun dapat lebih terpicu. Konsep dari Music Video atas lagu 'Di Udara' dilandasi oleh imajinasi akan kekerasan yang menimpa aktivis. Secara keseluruhan, pesan disampaikan melalui metode konotatif. Visual dalam video ini juga disertai kode-kode yang berisi sebuah pesan.

Penelitian ini dirumuskan pada 2 masalah yaitu bagaimana memberitahu masyarakat akan ketidak adilan yang menimpa aktivis melalui video musik pop? dan apa saja pesan politik yang terdapat dalam visual video musik 'Di Udara'? Sedangkan tujuan dari penelitian ini sendiri ada dua, yakni, melanjutkan semangat dan perjuangan para aktivis melalui music video, serta menemukan konsep visual yang komunikatif untuk menyampaikan pesan perjuangan para aktivis kepada masyarakat.

\section{METODE PENELITIAN}

\section{A. Objek Penelitian}

Objek utama dari penelitian ini adalah music video dari band Efek Rumah Kaca yang berjudul ' $\mathrm{Di}$ Udara'. Objek lain dalam penelitian ini adalah tokoh Munir sebagai dasar inspirasi dari pembuatan music video ini.

\section{B. Jenis Penelitian}

Pada penelitian Video Musik Di Udara ini jenis penelitian yang digunakan adalah kajian, dimana Video Musik berjudul Di Udara dari Efek Rumah Kaca ini menjadi objek penelitiannya dan dikaji pesan politik yang terkandung dengan menggunakan teori semiotika.

\section{Metode Pengumpulan Data}

\section{Studi Pustaka}

Penelitian ini diawali dengan studi literatur mengenai tokoh Munir dan teori semiotika.

\section{Analisis}

Dilanjutkan dengan menganalisa visual yang ada di dalam video musik. Visual tersebut dianalisa pesan politik yang terkandung di dalamnya dengan menggunakan teori semiotika.

\section{HASIL DAN PEMBAHASAN}

\section{A. Hasil Studi Literatur}

\section{Munir}

Gambar 1. adalah Munir, tokoh yang menjadi dasar inspirasi pembuatan video musik 'Di Udara' dari band Efek Rumah Kaca. Munir adalah seorang aktivis yang membela Hak Asasi Manusia. Nama lengkap dari aktivis HAM ini adalah Munir Said Thalib. Ia adalah seorang keturunan Arab yang lahir di Malang, Jawa Timur, 8 Desember 1965. Munir pernah menjabat sebagai Dewan Kontras, saat itu namanya dikenal sebagai seorang pejuang bagi orang-orang hilang yang diculik. Jabatan terakhir Munir adalah sebagai Direktur Eksekutif Lembaga Pemantau Hak Asasi Manusia Indonesia Imparsial. Ketika itu dia membela para aktivis yang menjadi korban penculikan Tim Mawar dari Kopassus.

Di usia 38 tahun, 7 September 2004, Munir meninggal dunia di perjalanannya menuju Amsterdam, Belanda. Ia meninggal dunia di dalam Pesawat Garuda nomor penerbangan GA-974. Munir berangkat ke Belanda untuk menghadiri seminar dan sekaligus mengurus bea siswa yang diterimanya dari Inggris (British Achievening Awards). Aktivis HAM Munir yang aktif dalam memperjuangkan korban penculikan juga dikenal sebagai seorang yang gigih dalam membela orang-orang tertindas.

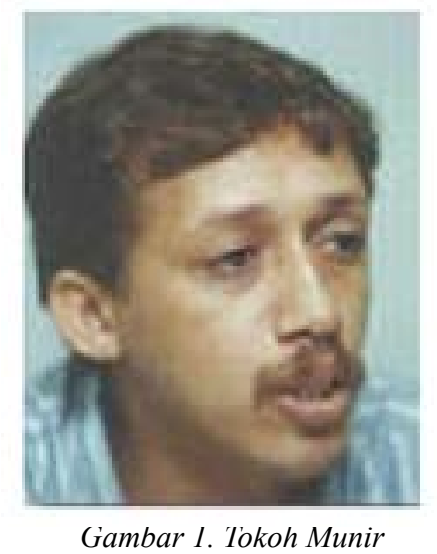

Efek Rumah Kaca merupakan Band Indie yang menawarkan musik yang sarat akan kritik sosial. Tema-tema yang mereka usung tidak pernah jauh dari isu-isu yang tengah terjadi saat ini. 


\section{Efek Rumah Kaca}

Band Indie ini terbentuk pada tahun 2001 dengan genre psychedelic pop. Selain topik hak asasi manusia seperti pada lagu Di Udara, band ini memiliki lagu lainnya yang sarat akan kritik sosial. Beberapa diantaranya adalah, Jalang, yang mengkritik Rancangan Undang-Undang Anti-Pornografi dan Pornoaksi; Belanja Terus Sampai Mati tentang budaya hidup konsumerisme; dan Cinta Melulu, yang mengkritik industri musik pop yang mayoritas mengangkat tema cinta.

Menurut Cholil, vokalisnya, lagu yang mereka hasilkan merupakan bagian dari usaha memotret zaman. "Musik sudah menjadi media komunikasi, tempat kami beropini," ujarnya sembari menyebut genre musik mereka adalah pop. Dia juga sempat berkata, "Karena ide (melalui pop) ini pasti lebih mudah diterima."

\section{Filosofi Lagu 'Di Udara'}

Lagu bertajuk 'Di Udara' diciptakan oleh Cholil vokalis band indie Efek Rumah Kaca. Penciptaan lagi ini terinspirasi oleh aktivis Munir yang tewas diracun di perjalanannya menuju Amsterdam, Belanda.

Lagu ini didedikasikan untuk tokoh Munir. "Setiap hasil yang diperoleh dari lagu itu kami donasikan untuk Munir Institute. Ini bentuk penghargaan setinggi-tingginya untuk inspirasi lagu ini, yaitu Munir," kata vokalis dan gitaris band itu, Cholil, kepada Tempo. Tujuan lain pembuatan lagu ini adalah agar kasus Munir tidak hanya dikenal oleh kalangan politisi dan orang-orang yang tertarik pada dunia politik saja. Generasi muda khususnya yang menyukai genre music pop juga bisa mengenal tokoh Munir melalui lagu ini. Diharapkan melalui lagu ini dapat melahirkan Munir-munir lain.

Alasan lagu ini dikemas dalam genre pop menurut band ini adalah karena mayoritas masyarakat Indonesia lebih menyukai musik dengan genre pop sehingga lagu ini dapat lebih mudah diterima. Isi dari lirik lagu ini berisi kisah perjuangan aktivis di Indonesia dengan kisah Munir sebagai fokus utamanya.

\section{Semiotika}

Semiotika (juga disebut studi semiotika) adalah studi tentang pembuatan makna, studi tentang proses tanda (semiosis) dan komunikasi yang bermakna. Ini bukan tradisi Saussurean yang disebut semiologi, yang merupakan subset dari semiotika. [1][2]. Semiotika sering dilihat memiliki dimensi antropologis dan sosiologis yang penting. Ahli semiotika dan novelis Italia Umberto Eco mengatakan bahwa setiap fenomena budaya dapat dipelajari sebagai komunikasi. [3] Sedangkan menurut Yasraf Amir Piliang, semiotika adalah ilmu tentang tanda dan kode-kode. [4]

\section{B. Analisa Visual Video Musik 'Di Udara-Efek Rumah Kaca'}

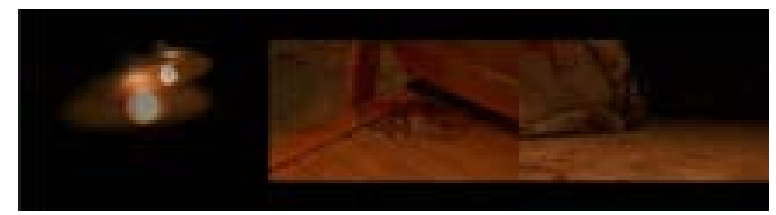

Gambar 2. Intro

Gambar 2 adalah scene Intro dari video music 'Di Udara'. Makna Denotatif dalam scene ini antara lain, lampu lama yang bergoyang, seseorang diikat tangannya diseret di lantai, dan kacamata pecah di atas kursi bernoda darah. Makna Konotatif yang terkandung adalah kekerasan Ikon yang tampak ialah lampu, kursi, kacamata, darah, dan punggung manusia. Sedangkan indeks yang terdapat adalah noda darah di kursi, lantai dan baju, serta kacamata pecah. Kode yang terkandung yaitu kode Hermeneutik.

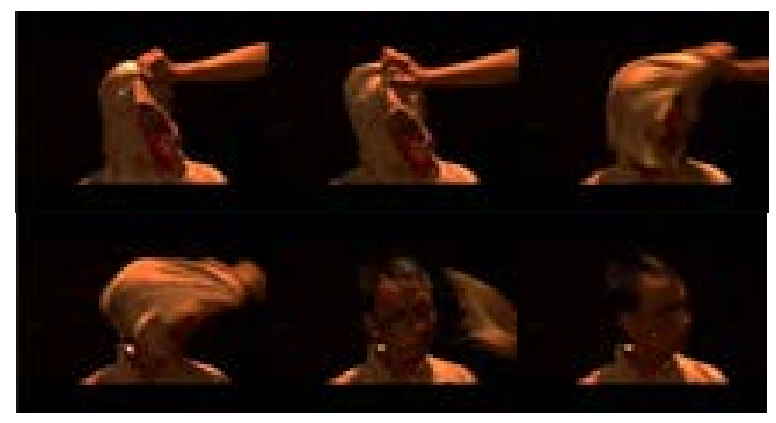

Gambar 3. Adegan 1

Gambar 3 adalah scene adegan 1 dari video music 'Di Udara'. Makna Denotatif dalam adegan 1 adalah seseorang yang ditutup kepalanya dengan karung bernoda darah, karung ditarik oleh sebuah tangan, wajah babak belur. Sedangkan makna Konotatifnya adalah kekerasan dan penculikan. Ikon yang tampak antara lain karung berlubang sebagai tutup kepala, seseorang berwajah babak belur. Indeks yang juga tampak yaitu, darah yang terdapat di tutup kepala dan wajah. Kode yang dipakai merupakan kode semantik.

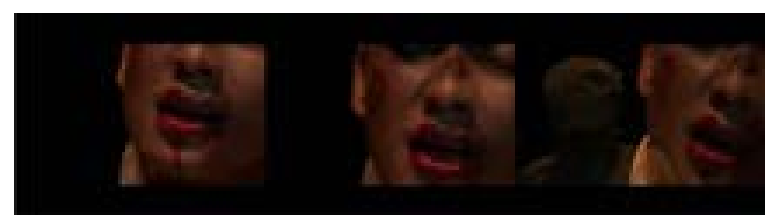

Gambar 4. Adegan 2 
Gambar 4 adalah scene adegan 2 dari video music 'Di Udara'. Lirik dalam adegan 2 adalah "Aku sering diancam". Makna denotatif dalam adegan 2 adalah wajah babak belur. Sedangkan makna konotatifnya ialah lemah dan kesakitan. Ikon yang tampak antara lain wajah seseorang yang terluka. Indeks yang tampak antara lain darah dan luka. Sedangkan kode yang dipakai adalah kode Semantik.

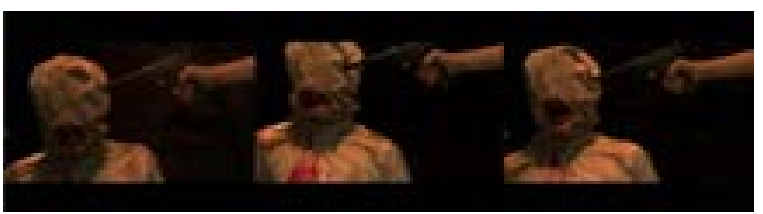

Gambar 5. Adegan 3

Gambar 5 adalah scene adegan 3 dari video music 'Di Udara'. Lirik pada adegan 3 berbunyi "Juga teror mencekam". Makna denotatifnya adalah tangan yang tengah memegang pistol yang diarahkan ke kepala yang ditutup oleh karung bernoda darah. Sedangkan makna konotatifnya ialah pembunuhan. Ikon yang tampak antara lain pistol, tutup kepala, tangan, dan sosok seorang pria. Indeks yang terlihat dalam adegan ini antara lain darah di baju dan bibir, serta baju yang robek. Kode yang dipakai yaitu kode semantik, dan kode hermeunetik.

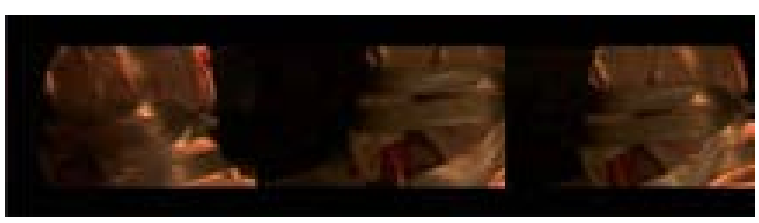

Gambar 6. Adegan 4

Gambar 6 adalah scene adegan 4 dari video music 'Di Udara'. Lirik dalam adegan 4 adalah "Kerap ku disingkirkan". Makna denotatif dalam adegan 4 adalah kepala seseorang yang ditutup kain putih dililit lakban. Sedangkan makna konotatifnya ialah penyekapan. Ikon yang tampak antara lain kain dan lakban. Indeks yang tampak antara lain kepala yang ditutup kain dan dililit lakban. Sedangkan kode yang dipakai adalah kode hermeunetik.

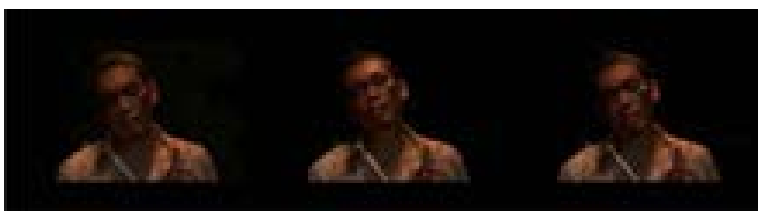

Gambar 7. Adegan 5

Gambar 7 adalah scene adegan 5 dari video music 'Di Udara'. Lirik pada adegan 5 adalah "Sampai dimana kapan?". Makna Denotatif dalam scene ini antara lain, seseorang yang babak belur memakai kemeja putih bernoda darah. Makna Konotatif yang terkandung adalah lemah, tak berdaya. Ikon yang tampak ialah kemeja putih dan sosok pria. Sedangkan indeks yang terdapat adalah noda darah di kemeja dan wajah. Kode yang terkandung yaitu kode hermeunetik dank ode semantik.

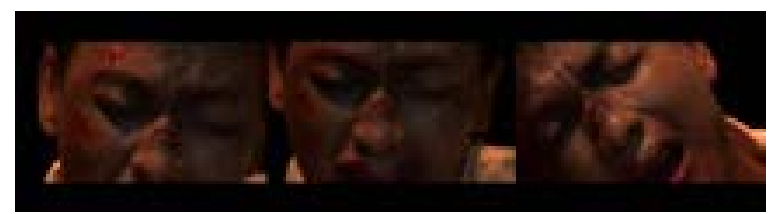

Gambar 8. Adegan 6

Gambar 8 adalah scene adegan 6 dari video music 'Di Udara'. "Ku bisa tenggelam di lautan, aku bisa diracun di udara, aku bisa terbunuh di trotoar jalan" adalah lirik pada adegan 6. Makna denotatifnya adalah wajah babak belur. Sedangkan makna konotatifnya ialah lemah, kesakitan. Ikon yang tampak antara lain wajah seseorang yang terluka. Indeks yang terlihat dalam adegan ini antara lain darah dan luka. Kode yang dipakai yaitu kode semantik, dan kode hermeunetik.

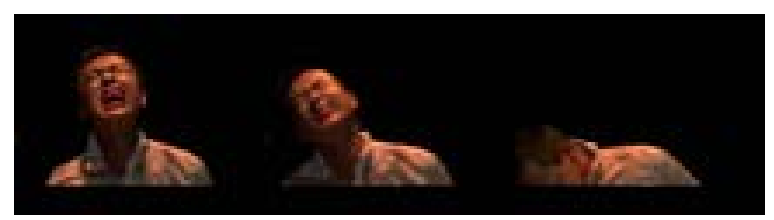

Gambar 9. Adegan 7

Gambar 9 adalah scene adegan 7 dari video music 'Di Udara'. "Tapi aku tak pernah mati, tak akan berhenti" adalah lirik pada adegan 9. Makna Denotatif dalam adegan 7 adalah seorang pria memakai kemeja putih dengan wajah berdarah. Sedangkan makna Konotatifnya adalah berteriak marah dan sedih. Ikon yang tampak antara lain kemeja bernoda darah, figur pria dengan wajah berdarah. Indeks yang juga tampak yaitu, darah di baju, mulut dan wajah. Kode yang dipakai adalah kode semantik dan kode hermeneutik.

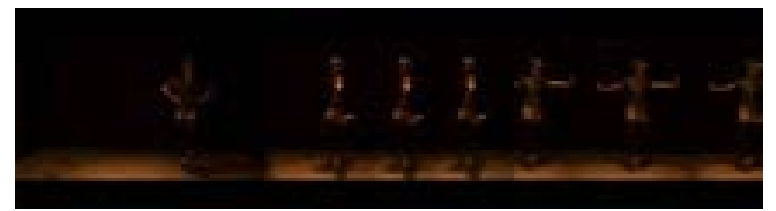

Gambar 10. Adegan 8

Gambar 10 adalah scene adegan 8 dari video music 'Di Udara'. Makna Denotatif dalam scene ini antara lain, 3 wanita berseragam militer bersepatu ballet menari ballet. Makna Konotatif yang terkandung adalah tentara dengan image ballerina, serigala berbulu domba. Ikon yang tampak ialah figur wanita, seragam militer, sepatu ballet. Sedangkan indeks yang terdapat adalah bayangan di lantai. Kode yang terkandung yaitu kode fashion dan insignia.

Gambar 11 adalah scene adegan 9 dari video music 'Di Udara'.Lirik pada adegan ini adalah "Aku 


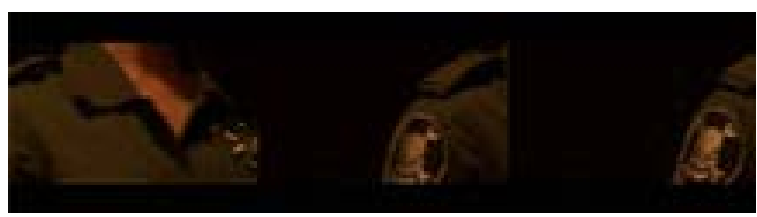

Gambar 11. Adegan 9

sering diancam, juga teror mencekam". Makna denotatif dalam adegan 9 adalah seragam tentara dengan gambar tengkorak. Sedangkan makna konotatifnya ialah figur kejam. Ikon yang tampak antara lain figur wanita berseragam. Indeks yang tampak antara lain kepala yang ditutup kain dan dililit lakban. Sedangkan kode yang dipakai adalah kode insignia dan kode fashion.

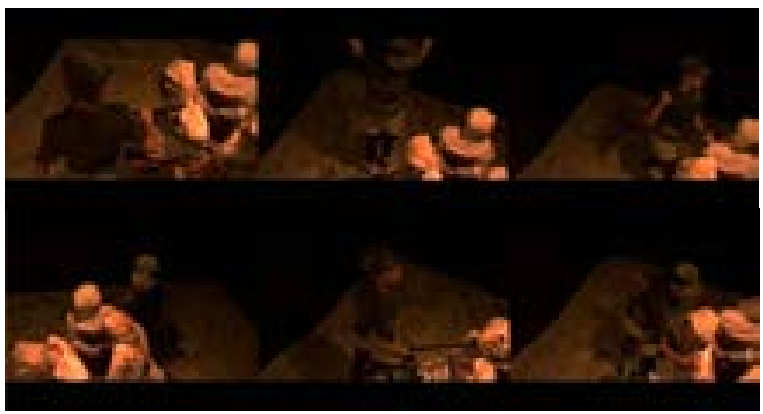

Gambar 12. Adegan 10

Gambar 12 di atas adalah scene adegan 10 dari video music 'Di Udara'. Lirik pada adegan ini adalah "Aku bisa dibuat menderita, aku bisa dibuat tak bernyawa". Makna denotatifnya adalah Tentara wanita mengelilingi 3 orang yang diikat dan ditutup kepalanya. Sedangkan makna konotatifnya ialah penyekapan. Ikon yang tampak antara lain kain sebagai tutup kepala, 3 figur pria diikat, figur tentara wanita, pistol. Indeks yang terlihat dalam adegan ini antara lain darah di tutup kepala dan baju. Kode yang dipakai yaitu kode fashion, dan kode insignia.

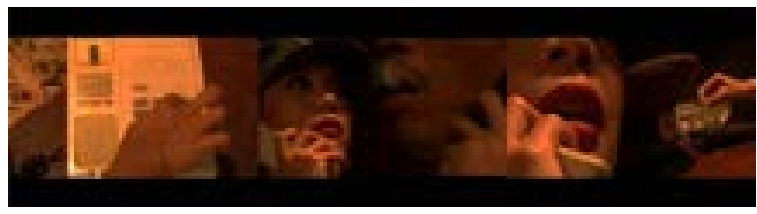

Gambar 13. Adegan 11

Gambar 13 di atas adalah scene adegan 11 dari video music 'Di Udara'. Makna Denotatif dalam adegan 11 adalah seseorang menekan tombol telepon, tentara wanita dan figur pria yang merokok sedang berbicara di telepon. Sedangkan makna Konotatifnya adalah persekongkolan. Ikon yang tampak antara lain figur pria, tentara wanita, telepon, rokok, asbak. Indeks yang juga tampak yaitu, asap rokok. Kode yang dipakai adalah kode semantik, kode fashion dan kode insignia.

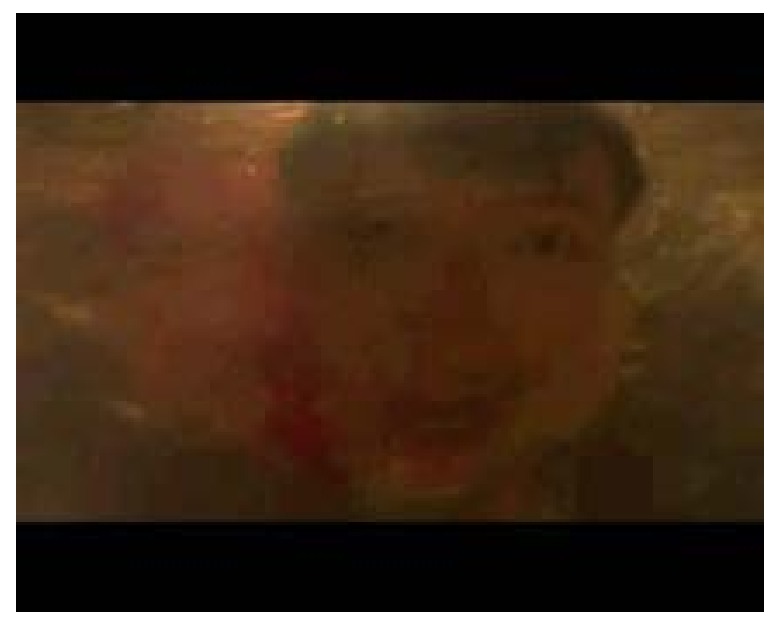

Gambar 14. Adegan 12

Gambar 14 di atas adalah scene adegan 12 dari video music 'Di Udara'. Lirik pada adegan ini adalah "Ku bisa tenggelam di lautan, aku bisa diracun di udara, aku bisa terbunuh di trotoar jalan". Makna denotatifnya adalah kepala seorang pria berdarah masuk ke air. Sedangkan makna konotatifnya ialah kekejaman dan penganiayaan. Ikon yang tampak antara lain figur pria, air, darah. Indeks yang terlihat dalam adegan ini yaitu darah. Kode yang dipakai yaitu kode semantik dan kode hermeneutik.

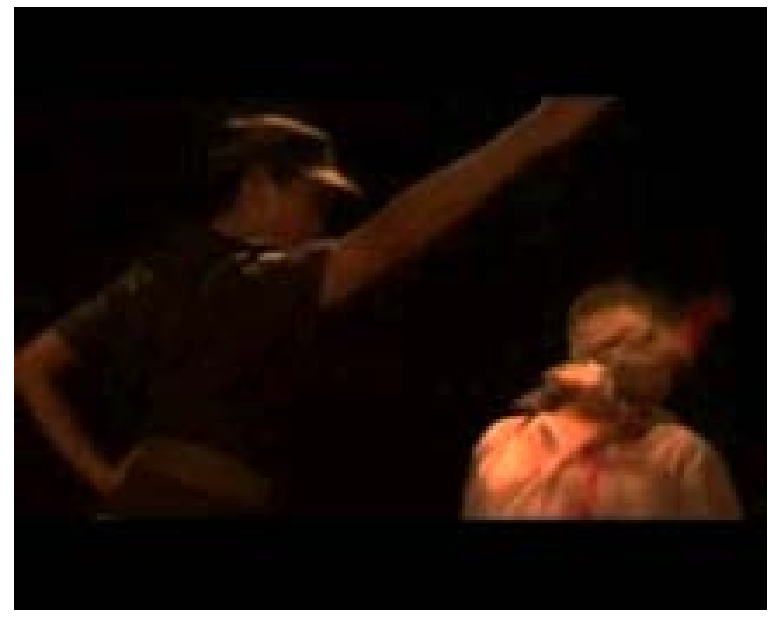

Gambar 15. Adegan 13

Gambar 15 adalah scene adegan 13 dari video music 'Di Udara'. Lirik pada adegan ini adalah "Tapi aku tak pernah mati, tak akan berhenti". Makna Denotatif dalam adegan 13 adalah figur pria ditutup kepalanya dipukul oleh tentara wanita sampai berdarah. Sedangkan makna Konotatifnya adalah kekerasan dan penganiayaan. Ikon yang tampak antara lain figur pria, tentara wanita, darah. Indeks yang juga tampak yaitu, darah di baju dan tutup kepala. Kode yang dipakai adalah kode semantik dan kode fashion.

Gambar 16 adalah scene adegan 14 dari video music 'Di Udara'. Lirik pada adegan ini adalah “Tapi 


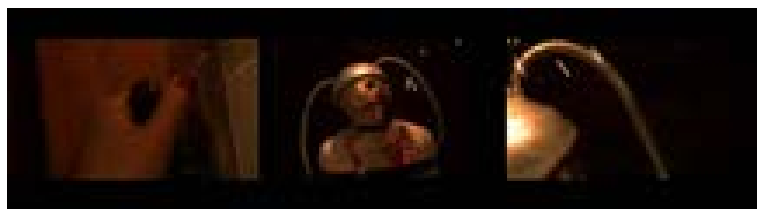

Gambar 16. Adegan 14

aku tak pernah mati, tak akan berhenti”. Makna Denotatif dalam scene ini antara lain, tangan dengan cat kuku menarik tuas berwarna hitam, figur pria yang ditutup kepalanya memakai topi berkabel. Makna Konotatif yang terkandung adalah pembunuhan. Ikon yang tampak ialah figur pria, tangan wanita, topi listrik, percikan listrik. Sedangkan indeks yang terdapat adalah percikan listrik, darah di baju dan tutup kepala. Kode yang terkandung yaitu kode naratif=pria dibunuh oleh wanita dengan menggunakan listrik.

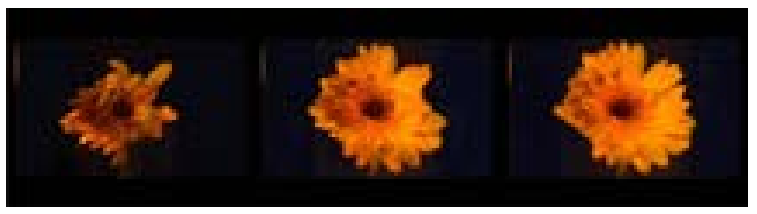

Gambar 17. Adegan 15

Gambar 17 di atas adalah scene adegan 15 dari video music 'Di Udara'. Lirik pada adegan ini adalah "Tapi aku tak pernah mati, tak akan berhenti". Makna denotatifnya adalah bunga berwarna kuning mekar. Sedangkan makna konotatifnya ialah kebangkitan. Ikon yang tampak yaitu bunga. Indeks yang terlihat dalam adegan ini yaitu bunga mekar. Kode yang dipakai yaitu kode semantik.

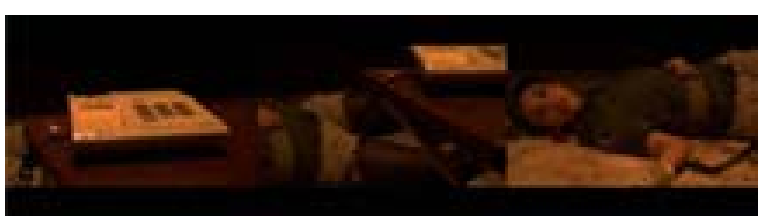

Gambar 18. Adegan 16

Gambar 18 adalah scene adegan 16 dari video music 'Di Udara'. Makna Denotatif dalam adegan 16 adalah telepon di atas meja, gagangnya dipegang oleh tentara wanita yang terbujur kaku di lantai dengan darah mengalir dari mulutnya. Sedangkan makna Konotatifnya adalah pembunuhan. Ikon yang tampak antara lain : telepon, tentara wanita, darah, meja. Indeks yang tampak yaitu, gagang telepon di tangan, darah di lantai. Kode yang dipakai adalah kode naratif dan kode fashion.

\section{SIMPULAN}

Kesimpulan yang dapat ditarik dari analisa visual di atas adalah secara keseluruhan, konteks politik di video musik ini divisualisasikan secara konotatif dan persuatif dengan menggunakan proairetic code, konsep visual dalam video musik ini bertujuan membangun emosi audience, video musik ini bertujuan mengobarkan semangat aktivis dan melahirkan aktivis-aktivis lain, video musik menjadi sarana yang diharapkan lebih efisien dalam menginformasikan realita yang ada.

\section{DAFTAR RUJUKAN}

[1] A. Shepperson \& Tomaselli, 1993, K.: Semiotics in an Africal Context: "Science" vs. "priest-craft" "semiology" vs. "semiotics". Acta Semiotica Fennica II: On the Borderlines of Semiosis. Edited by E. Tarasti, Publications of the International Semiotics Institute at Imatra, no 4, hal. 159-175.

[2] M. Bal, \& N. Bryson, 1991, Semiotics and Art History, Art Bulletin 73, no. 2, Hal. 174-208.

[3] M. Caesar 1999, Umberto Eco: Philosophy, Semiotics, and the Work of Fiction, Wiley-Blackwell, hal. 55.

[4] Y. A. Piliang 2010, Semiotika dan Hipersemiotika, Edisi 4, Bandung: Matahari, hal.340. 